\title{
PÖÖRATUD POLAARSUSEGA RETOORILISED KÜSIMUSED ARGIVESTLUSES
}

\author{
KIRSI LAANESOO
}

\section{Sissejuhatus}

$\Lambda^{2}$ rtikli eesmärgiks on analüüsida ja kirjeldada pööratud polaarsusega küsimusi loomulikus suulises suhtluses. Pööratud polaarsusega küsimused on retoorilised küsimused, mis edastavad küsimuse jaatusele-eitusele vastupidiseid väiteid. Selliselt on üldjuhul defineeritud kõiki retoorilisi küsimusi erinevates allikates, sealhulgas erinevate keelte grammatikates (nt Ilie 1995; EKG II; Quirk jt 1976), kuid leian, et on olemas erinevat liiki retoorilisi küsimusi ja ainult teatud retooriliste küsimustega on võimalik väljendada jaatusele-eitusele vastupidiseid väiteid. Retooriliste küsimuste all pean üldiselt silmas küsimuse vormis väiteid, mis sisaldavad nii küsimuse kui ka sellele mõeldud vastuse.

Artiklis käsitlen ühte retooriliste küsimuste alaliiki, mille kirjeldamiseks on kasutusele võetud termin pööratud polaarsusega küsimused (reversed polarity questions, edaspidi PPK) (Koshik 2005). Polaarsus on kategooria, mis hõlmab lause eitust ja jaatust. Pööratud polaarsus tähendab seda, et lausel on vormilt üks polaarsus, sisult aga teine. PPK-de puhul vormilt jaatav küsimus edastab sisult eitavat väidet ja vastupidi. Näiteks vormilt jaatav PPK Keda see huvitab? väljendab sisuliselt eitavat väidet See ei huvita kedagi.

Eitav PPK väljendab aga jaatavat väidet (Kas mul ei olegi õigus arvustada? - Mul on õigus arvustada.).

Eesti keeles ei ole retoorilisi küsimusi suulise suhtluse materjali põhjal varasemalt käsitletud. Vähesel määral kirjeldavad retoorilise küsimuse keelelist väljendusvormi - retoorilist küsilauset - teaduslik eesti keele grammatika (EKG II) ja Helle Metslangi „Küsilause eesti keeles” (1981). Sarnase tähendusega küsilause konstruktsioone on pragmaatilisest aspektist vaadelnud Renate Pajusalu (2006).

Käesoleva artikli analüüsi aluseks on autentsed argivestlused, milles leidunud PPK-sid olen käsitlenud vestlusanalüüsi ja suhtluslingvistika meetodeid kasutades. Analüüsimisel olen lähtunud eelkõige sellest, kuidas vestlejad ise analüüsivad suhtluses ettetulevaid pööratud polaarsusega retoorilisi küsimusi.

\section{Retooriline küsimus ja infoküsimus}

Et käsitlen PPK-sid retoorilise küsimuse alaliigina, võib neid iseloomustada valdavalt samade tunnusjoontega, millega kõiki teisigi retoorilisi küsimusi (vt tabel 1). Omadus, mis eristab PPK-sid teistest retoorilistest küsimustest, on see, et kuigi kõik retoorilised küsimused funktsioneerivad seisu- 
kohtadena, siis ainult PPK-d väljendavad sõnastatule vastupidiseid seisukohti. Võtame näiteks kaks retoorilist küsimust - Kas taevas on sinine? ja Keda see huvitab? Retoorilises küsimuses Kas taevas on sinine? ei avaldu jaatusele-eitusele vastupidist seisukohta, vaid sellega edastatav väide (taevas on sinine) on sama (jaatava) polaarsusega kui küsimuski. Teisalt retooriline küsimus Keda see huvitab? väljendab vastupidise polaarsusega (eitavat) väidet (see ei huvita kedagi).

Eesti keeles on seni kõiki retoorilisi küsimusi kirjeldatud enamasti väite ja küsimuses avalduva polaarsuse nihke kaudu. Eesti keele grammatika kirjeldab retoorilisi küsilauseid kui küsilausete sekundaartähenduste alla kuuluvaid küsimusi ja defineerib retoorilist küsilauset kui väidet, mis on jaatuse-eituse poolest sõnastatule vastupidine (EKG II: 174). Helle Metslangi sõnul „retooriline küsilause vormistub eesti keeles nagu kahtlusküsilause, kuid kommunikatiivselt ja loogiliselt on ta väide" (Metslang 1981: 105). Metslang kirjeldab retoorilist küsilauset ka semantika kaudu, väites: „Teatud retoorilistes küsilausetes esitatud propositsioon on semantiliselt vasturääkiv või absurdne, tehes ainuvõimalikuks vastupidise vastuse (nt Kas päike on kandiline?)" (1981: 106).

Retoorilise küsimuse (nt Kas taevas on sinine?) ja infoküsimuse (nt Mis kell on?) vahel on mitmeid märkimisväärseid erinevusi, mis tulenevad sellest, et retoorilisel küsimusel on lisaks küsimuse tunnustele ka väitele omaseid tunnusjooni. Olulisemaks erinevuseks retoorilise küsimuse ja infoküsimuse vahel on see, et retoorilise küsimusega väljendatakse küsijale juba teada olevat infot väitena ja vastuse ootus ei ole seega eriti suur. Infoküsimus aga esitataksegi selleks, et täita puuduv infolünk, ja seetõttu on vastus sellele äärmiselt oluline. Vestlusanalüüsi seisukohalt on oluline erinevus retoorilise küsimuse ja infoküsimuse vahel veel see, et kui infoküsimusele vastamata jätmine tekitab vestluse sujuvuses probleeme, siis üldjuhul retoorilise küsimuse puhul vastuse puudumine ei mõjuta vestluse edasist kulgu. Kuna retooriline küsimus sisaldab implitsiitset vastust, võib kaasvestleja reaktsioon sellele jääda mentaalseks ja seda pole vaja eraldi sõnastada. Infoküsimuse vastus tuleb aga verbaliseerida, et tulla vastu küsija soovile saada uut infot (Ilie 1995: 129).

\section{Materjal ja meetod}

Uurimuses kasutan pööratud polaarsusega küsimuste kirjeldamiseks ja analüüsimiseks üksteisega tihedalt seotud suulise keele uurimismeetodeid: suhtluslingvistikat ja vestlusanalüüsi. Mõlema meetodi aluseks on vestluste mikroanalüüs, mis võimaldab materjalile kvalitatiivselt läheneda.

Suhtluslingvistika vaatleb, milliseid keelelisi vahendeid inimesed suhtluses kasutavad, et läbi viia soovitud tegevusi. Uuritakse, kuidas keelelised struktuurid ja mustrid kujundavad suhtlust, ja teisalt, kuidas suhtlus kujundab neid mustreid. Suhtluslingvistikas kasutatakse materjali analüüsimiseks erinevaid keeletasandeid - foneetikat, fonoloogiat, morfoloogiat, süntaksit, leksikat, semantikat ja pragmaatikat (Couper-Kuhlen, Selting 2001; Keevallik 2002). 
Tabel 1.

\section{Retoorilise ja infoküsimuse peamised erinevused ${ }^{1}$}

\author{
RETOORILINE KÜSIMUS \\ - sisaldab implitsiitset vastust, \\ mis on vastajale järeldatav \\ - toimib korraga nii küsimusena \\ kui ka seisukohana \\ - võib toimida eelneva \\ küsimuse vastusena \\ - kutsub esile mentaalse vastuse, \\ võib saada verbaalse vastuse \\ - võib saada reaktsiooniks \\ nõustumise või mittenõustumise \\ - põhineb infol, mis on teada \\ nii küsijale kui ka vastajale
}

\author{
INFOKÜSIMUS \\ - ei sisalda implitsiitset vastust \\ - toimib tavaliselt verbaalset vastust \\ esile kutsuva küsimusena \\ - ei saa tulemusrikkalt toimida \\ eelneva küsimuse vastusena \\ - kutsub esile verbaalse vastuse \\ - sellele ei saa üldjuhul reageerida \\ nõustumise ega mittenõustumisega \\ - põhineb infol, mis on eeldatavalt teada \\ ainult vastajale
}

Vestlusanalüüs uurib samuti suulist suhtlust, sealjuures norme ja seaduspärasusi, mida kõnelejad suheldes järgivad. Vestluste mikroanalüüsi aluseks on järgmised küsimused: kuidas on vestluses voorud ja järjendid liigendatud ning kuidas töötab vooruvahetusmehhanism; kuidas kõnelejad parandavad nii enda kui ka kaasvestleja kõnes ettetulevaid vigu ja arusaamatusi? Lisaks vaatleb vestlusanalüüs, kuidas moodustatakse vestluses erinevaid suhtlustegevusi (vt Sacks, Schegloff, Jefferson 1974; Schegloff, Sacks 1973; Schegloff, Jefferson, Sacks 1977; Drew, Heritage 2006; Liddicoat 2007; Kasterpalu, Gerassimenko 2006).

Lähtun analüüsimisel ühest olulisemast vestlust juhtivast järjendiliigendusest - naabruspaariliigendusest, mille kohaselt teatud kõnevoorud moodustavad järjendeid, mis on jagatavad esi- ja järelliikmeks, mis asuvad vestluses üldiselt kõrvuti ja on eri kõnelejate esitatud. Naabruspaarid on näiteks küsimus-vastus, tervitus-vastutervitus. Naabruspaari üheks peamiseks omaduseks on, et esiliige määrab järelliikme (Schegloff, Sacks 1973: 295-296). Põhinedes naabruspaaride liigendusel, mille kohaselt küsimus moodustab koos vastusega tervikliku sekventsi, ei ole võimalik küsimusi ja vastuseid suulises suhtluses eraldi uurida. Seetõttu olen analüüsimisel vaatluse alla võtnud lisaks küsimustele ka nendele eelnevad ja järgnevad voorud.

Uurimismaterjaliks on spontaansed argivestlused, mis on kogutud Tartu Ülikooli suulise eesti keele korpusest. Uuritud 84 argivestluses leidus 42 pööratud polaarsusega küsimust. Käsitlen ainult küsilausena vormistatud küsimusi, seega PPK-de otsimisel lähtusin küsilause üldistest grammatilistest tunnustest, see tähendab, et päringuna esitasin küsipartiklid ja küsisõnad. Saadud tulemuste hulgast otsisin omakorda välja pööratud polaarsusega küsimused.

Analüüsitavad vestlused on silmast silma argivestlused, milles osalejad on sugulased või head tuttavad. Kuna suhtlussituatsioonid on igapäevased,

1 Tabel põhineb osaliselt Cornelia Ilie uurimusel (1995: 129), kuid olen kohandanud seda vastavalt oma uurimistulemustele. 
mitteametlikud, valitseb vestlustes suhteliselt vaba ja loomulik õhkkond. Vestlussituatsioonideks on enamasti söögilauavestlused või muud koosistumised, milles vestlejad räägivad erinevatel teemadel. Muuhulgas arutletakse vestlustes näiteks eesti kirjanduselu, poliitika ning kaupade hindade üle.

Artiklis vaatlen pööratud polaarsusega küsimuste grammatilist ülesehitust; sekventsiaalset ehk järjendilist positsiooni vestluses; samuti käsitlen küsimusi nendele järgneva reaktsioonivooru seisukohast ja kõiki eespool nimetatud vaatenurki arvestades analüüsin pööratud polaarsusega küsimuste suhtluslikku eesmärki.

\section{Pööratud polaarsusega küsimuste ülesehitus}

PPK-de struktuuri uurimine näitas, et neid küsimusi vormistatakse samal viisil ja samade vahenditega kui infoküsimusi. Kõige rohkem PPK-sid esineb eriküsimuste hulgas (tabel 2). Pööratud polaarsusega valikküsimuste kohta, mis väljendavad seisukohta, leidus neli näidet. Pööratud polaarsusega valikküsimused moodustatakse küsisõna kas ja lauselõpulise partikli või abil. Eriküsimuste hulgas moodustatakse enim pööratud polaarsusega küsimusi küsisõnaga mis, mis tuleneb sellest, et mis võib (eelkõige) suulises kõnes asendada ka teisi küsisõnu, näiteks miks ja mida. mis-algulistele pööratud polaarsusega küsimustele järgnevad arvukuselt kus-algulised küsimused, mida leidus materjali hulgas kuuel korral. Analüüsil selgus, et samuti saab tulemusrikkalt väljendada väiteid vastaspolaarsusest miks- ja kes-alguliste (ja selle käändeliste variantide keda, kelle, kellele) küsimuste abil.

Et PPK-sid vormistatakse samamoodi kui infoküsimusi, võib selguda alles vestluse laiemas kontekstis, et tegemist on PPK-ga. Siinkohal vaatame järg-

Tabel 2.

\section{Erinevad küsisõnad ja -partiklid pööratud polaarsusega küsimustes}

\begin{tabular}{|c|c|c|}
\hline $\begin{array}{l}\text { KÜSISÕNA/ } \\
\text {-PARTIKKEL }\end{array}$ & $\begin{array}{l}\text { ESINEMUSI } \\
(\text { kokku 42) }\end{array}$ & NÄIDE \\
\hline KAS+VÕI & 2 & kas me ei `ela demo`kraatlikus 'vabariigis või. \\
\hline KAS & 2 & kas see `nimi peaks mulle midagi ütlema. \\
\hline KES & 4 & `kes ütleb kelle saatus see `parem on \\
\hline KELLE & 1 & `kelle se `asi on \\
\hline KEDA & 1 & aga `keda see `uvitab. \\
\hline KELLELE & 2 & `kellele `kurat seda `vaja läheb \\
\hline KUS & 6 & kus `mina tean mis seal `on \\
\hline KUST & 1 & `kust ta 'muidu teadis et see 'vana inime on. \\
\hline MIKS & 5 & `miks on vaja nii võ̃ora [sõnaga `rääkida.] \\
\hline MIS & 16 & no 'mis on viga `noor 'olla \\
\hline MILLAL & 1 & ‘millal ma sinna ‘ähen. \\
\hline KUIDAS & 1 & $` k u d a$ ma ‘ulen kella `kolmeks \\
\hline
\end{tabular}


mist näidet² (näide 1), kus vestlejateks on $\mathrm{E}, \mathrm{VE}^{3}$ ( $\mathrm{E}$ ema) ja A (E minia). Jutt käib vestluses mitteosalevast inimesest Karinist, kes töötab koolis ja on haigestunud.

$01 \mathrm{E}$ : =aga siss see (1.6) noh mina=ei='TEA kas nende oma auto sis=ei `käi või, (1.0)

02 et kas sis `saab `Margusega või `Vahuriga tulla, (1.2) nemad olid andnud

03 telefoninumbrid, (0.8) et kui teie=ei tule sis Neeme läheb `ise järgi, (1.2) no

04 mina nüd `ka ei tea, eile `õhtal Kariniga rääkisime.

$05(0.6)$

06 A:aa

07 E: Karinil oli [HÄÄL] `NII `̈̈RA et piuks piuks ainult,

08 A: [tõesti]

$09 \mathrm{E}$ : heh mina=ei=tea=`kuss=ta=külmetas, ütles et päris on kodus haigus'lehel noh

10 rääkida ei saa mis=ta seal koolis teeb.

$11(0.4)$

12 A: s:oh

$13 \mathrm{E}$ : jah, (0.6) ütles et pidi homme lastega minema 'VALKA (1.0) aga et ta ei saagi

14 minna et Neeme peab minema vist vist.

15 (1.0)

$16 \mathrm{~A}: \mathrm{hm}=$

Küsilause Mis ta seal koolis teeb? (rida 10) võib kontekstist eraldi vaadelduna olla ka infoküsimus, mille puhul küsimuse esitaja tahab tõepoolest teada saada, mida kõne all olev inimene koolis teeb. Kui aga vaadata seda küsilauset vestluskontekstis, võib seda tõlgendada kui pööratud polaarsusega küsimust: vormiliselt jaatav küsilause sisaldab sõnastatule vastupidist - eitavat - väidet ta ei tee seal koolis midagi. PPK sisaldab seisukohta, et Karinil pole midagi koolis teha, sest tal ei ole häält. Küsimuse propositsiooniga esitatud tegevuse sooritamine on teatud mõttes võimatu. E kasutab PPK-d, et teha selle abil järeldus oma eelnevast jutust. Küsimus lõpeb langeva intonatsiooniga ja sellele järgneb paus. Need märgid viitavad sellele, et E on oma vooru lõpetanud ja keegi vestluskaaslastest võiks kõnevooru üle võtta. Pärast pausi alustabki vooru A. A-le on eelnevas voorus esitatu uus info, sellele osutab real $12 \mathrm{~s}:$ oh, mis väljendab üllatust. Uus info on see, et Karin on kodus haiguslehel.

PPK-le reageerimise seisukohast saab järeldada, et küsimust ei ole tõlgendatud infoküsimusena, kuna sellele ei järgne otsest vastust, vaid reageerimine $s$ :oh-iga on reaktsioon voorule kui tervikule. Selles vestluses tuleb hästi esile see, kui oluline on PPK-de tõlgendamisel kontekst ja kuidas vestluskaaslane on võimeline tajuma küsimuse retoorilisust konteksti kaudu.

Eespool kirjeldasin pööratud polaarsusega küsimusi, mis on vestluskontekstist sõltuvad, aga materjalis eristusid veel sellised PPK-d, mis on täielikult

2 Transkriptsioonimärgid on toodud artikli lõpus.

3 VE ei võta antud näitelõigus sõna, kuid on vestlussituatsioonis osaleja. 
või osaliselt kinnistunud ehk vormelistunud. Selliste küsimuste puhul on ka ilma täiendava suhtluskontekstita võimalik aru saada, et tegemist on pööratud polaarsusega küsimustega.

Vaatame lähemalt järgmises vestluskatkes (näide 2) esinevat küsimust aga `keda see `uvitab, mis on näide täielikult kinnistunud vormiga PPK-st. Selles vestluses räägivad söögilauas kaks sugulast $\mathrm{S}$ ja $\mathrm{P}$. P räägib oma nädalalõpuplaanidest.

$01 \mathrm{~S}: \quad[` r e e d e l]$ oled `tööl=vä.

/---/

02 P: 'Leiki täna ommikul `nägi mind ja=sis ta `ütles=et

03 (2.4) ((keegi segab tassis lusikaga))

04 P: @ Pille sa `pe:ad tulema, ei `saa muidu, @ kuigi ma ütsin@ @oi, et ma

05 olen `laubäeval \$ kella `kuueni `tööl, et `kuda ma`tulen kella ‘kolmeks.@ (0.6)

06 aga `keda see `uvitab. \$ (.) a=`muidugi: `võib juhtuda ka `nii=et näiteks kui

07 `mul (0.9) ma=i=`tea (0.6) `Aare rääkis midagi `sünnipäevast, et kui äkki mingi

08 `sünnipäevaleminek *'laubäeval sis (0.5) sis ma vist*`küll ei lähe sinna

09 'mängima.=hh

$10 \quad(1.5)$

$11 \mathrm{P}$ : või `siis ma=i tea

$12 \quad(0.2)$

$13 \mathrm{~S}: \quad$ mul jäi `kõht tühjaks. ((nukralt))

Analüüsitav küsimus asub pikas $\mathrm{P}$ voorus, mis järgneb S-i küsimusele, kas $\mathrm{P}$ on reedel tööl4 (rida 1). Pööratud polaarsusega küsimus esineb selles vestluse osas, kus P kirjeldab oma tänahommikust kohtumist Leikiga. Küsimus aga `keda see `uvitab väljendab seisukohta see ei huvita kedagi.

Reageerimise seisukohast võib vestlusest välja lugeda seda, et kumbki kõnelejatest ei käsitle seda küsimust küsimusena, millele oodatakse vastust. Pärast PPK-d tuleb mikropaus ja P jätkab oma kõnevooru, mis näitab, et ta ei oota kaasvestlejalt reaktsiooni. Vestluskaaslane $\mathrm{S}$ ei reageerigi sellele PPK-le kuidagi, mis näitab, et ta on seda küsimust tõlgendanud retoorilisena.

Ainus märk vestluses, mis võib osutada mingil määral reaktsiooni ootusele, on see, et kuni analüüsitava küsimuseni taasesitab $\mathrm{P}$ varem toimunud vestlust, aga PPK-d aga `keda see `uvitab võib tõlgendada kui käimasolevasse vestlussituatsiooni suunatud lausungit. Sellele osutab eelkõige see, et PPK-le eelnevad lausungid on esitatud saatelausega, mis on omane refereeringule suulises kõnes, analüüsitavas PPK-s seda aga ei ole kasutatud. Seega aga `keda see `uvitab ei kajasta enam minevikus toimunud situatsiooni, vaid see on teatud mõttes hinnang jutustatud olukorrale, millele teoreetiliselt kaasvestleja võiks reageerida. Tasub tähele panna, et PPK on esitatud naerdes, mis väljendab samuti teatud hinnangut. Sellegipoolest ei pea vestluskaaslane sellele PPK-le reageerimist vajalikuks.

4 Näite transkriptsioonist on välja jäetud read, mis ei osutunud selle PPK analüüsimise seisukohast oluliseks. 
Täiesti kinnistunud pööratud polaarsusega küsimuste alla kuuluvadki sellised küsimused, mille kasutus on väga levinud ja mille retoorilisus on küsimuse vormiga tihedalt seotud. Näiteks selles näites toodud Keda see huvitab? või Mis vahet seal on?. Sellised vormelistunud küsimused on olemas samuti teistes keeltes, nt inglise keeles Who cares? What difference does it make? (Koshik 2005: 64-67). Osa sellistest küsimustest on lühenenud ja seetõttu kinnistunud, nt mis teha, kes teab.

Osaliselt kinnistunud vormiga pööratud küsilauseteks loen selliseid küsilauseid, mis esinevad vestlustes enamasti ühesugusel kujul, kuid nendes on võimalik vastavalt olukorrale ja kõneleja soovile mõnda lause osa muuta. Näiteks lauseid Mis see sinu asi on? ja No mis sest kasu? võib muuta järgnevalt: Mis see tema asi on? Mis nendest kasu? jne.

Kokkuvõtvalt võib PPK-de ülesehituse kohta öelda, et need küsimused on üldjuhul vormistatud samamoodi kui infoküsimused. Osa PPK-sid on tuvastatavad ainult konteksti toel, teised on osaliselt või täielikult vormelistunud ja on seega kontekstist sõltumatud.

\section{Pööratud polaarsusega küsimuste järjendiline positsioon vestluses}

Selleks et kirjeldada PPK-de järjendilist asukohta, tuleb vestluste mikroanalüüsi teel välja selgitada, kuidas vestluskaaslased analüüsitavatele küsimustele reageerivad. Teisisõnu, vestlusanalüüsi ja suhtluslingvistika kohaselt saab järeldusi teha selle põhjal, kuidas vestlejad ise käsitlevad vestluses ette tulnud PPK-sid. Samuti on oluline arvestada, mis vestluses nendele küsimustele eelneb.

Analüüsitud materjalis esines kolm reageerimisvõimalust PPK-dele: tüüpiline reageerimisviis on väite või seisukohaga nõustumine või mittenõustumine, sageli jääb PPK-le reaktsioonivoor üldse saamata või sellele vastatakse hoopis otseselt nagu infoküsimusele.

PPK-dele reageerimise kaudu on võimalik välja selgitada, kas PPK moodustab mõne vooruga kokkukuuluva järjendi või mitte. Vastavalt sellele tulid analüüsitud vestlustes esile PPK-d, mis olid naabruspaari järjendi liikmed, ja PPK-d, mida ei olnud võimalik analüüsida naabruspaari osana

\subsection{Pööratud polaarsusega küsimused, mis kuuluvad naabruspaari}

Pööratud polaarsusega küsimused, mis kuuluvad naabruspaari, moodustavad kas seisukoht-nõustumine/mittenõustumine naabruspaari või küsimus-vastus naabruspaari.

5.1.1. Seisukoht-nõustumine/mittenõustumine naabruspaar. Et PPK-de põhiliseks tegevuseks vestluses on seisukoha väljendamine, kuulub enamik uuritud pööratud polaarsusega küsimustest naabruspaari seisukoht-nõustumine/mittenõustumine. Selles naabruspaari järjendis võivad PPK-d olla nii esiliikmed kui ka järelliikmed.

Järgnevad näited (3 ja 4) iseloomustavadki pööratud polaarsusega küsimusi naabruspaari seisukoht - nõustumine/mittenõustumine liikmetena.

Näite 3 vestluses osalevad neli inimest. A ja B on abielus, C on nende perekonnatuttav, D on A ja B-ga tuttav eelmisest õhtust saadik. Vestluse teemaks 
on raamatud ja kirjandus. A suhtub vestlusteemasse kohati irooniliselt. Selles vestluse osas on käimas arutelu teemal, kas eesti kirjanikud on „õiged” kirjanikud või mitte.

(3)

01 A: seal `samaseski kust `Ellen kirjutas seal `Urvaste kandis `sääl on üks 'Kontra `ka

02 ju, ega siss `see kurat pole vel `kirjanik o[metigi.]

$03 \mathrm{~B}:$ ((pisut irooniliselt)) [se=on `luule]taja muide.

$04(0.4)$

$05 \mathrm{C}$ : [`r(h)ahvalaulik.]

$06 \mathrm{~A}: \quad[\mathrm{minu}$ arust on=ta]

07 (.)

$08 \mathrm{D}: \quad$ ta on $\mathrm{r}][$ ohkem mingi ühiskonnategelan]e.

$09\{-\}:[\{-\}]$

$10 \mathrm{~A}: \quad[\mathrm{minu}=$ arust $\operatorname{minu}=$ arust on ta jah. $]$

$11(1.6)$

$12 \mathrm{C}$ : ise annab oma raamatud $[\{-\}]$

$13 \mathrm{~B}$ ['luuletaja] 'luuletaja nüüd on `seal [samases see]

$14 \mathrm{~A}$ : [minu=arust on neid 'küla]

15 napakaid Eestis `küllalt teat. hehe

$16 \mathrm{~B}$ : ei 'miks ta=i või ['olla, $\{--\}]$

$17 \mathrm{C}$ :

18 A:

[ei minu arust on=ta=selline] [`ehtne kuju=ja]

19 (.)

20 A: kuidas?

$21 \mathrm{~B}$ : `sina pole ka `mida[:gi.]

$22 \mathrm{C}$ :

23 A:

[`eht]ne ja `loomulik [kuju.]

$24 \mathrm{~B}:$

[`ehtne ja `loomulik] jah? [`seda `küll.]

$25\{\mathrm{C}\}$ :

$26 \mathrm{~A}:$ [just 'täpselt.]

[((köhatab))]

$27 \mathrm{~B}$ : [ega `sina ei ole] `arvustaja siin, ‘mitte `mingi[sugune.]

$28 \mathrm{~A}:$

$29 \mathrm{~A}$ : kas `minul ei o(h)legi õigus `arvustada või. [see on `oma] [see on `oma `a][si.]

$30(0.8)$

31A: to`hoo `taevas `appi. \$ kas me ei `ela demo`kraatlikus `vabariigis või. \$

$32 \mathrm{~B}:$ nooh?

$33 \mathrm{C}$ : > $\$$ ikka on `õigus.\$<

$34(0.6)$

$35 \mathrm{~B}$ : erilist $[\{-\}]$ ütlemist sul ei `ole `selle kohta.

36 A: $\quad[(($ köhatab $))]$

37 (4.3)

38 B: mt minu=melst oli [`siin] selles `Ekspressis `ka. ((otsib Contra kohta infot))

Vestluskatkes räägitakse Contrast ning vestlejad esitavad oma seisukohti ja isiklikke arvamusi tema kohta. Kuna A-l ja B-l on erinevad arvamu- 
sed käsitletavast teemast, muutub arutelu vestluse käigus vaidluseks, kus ühelt poolt süüdistatakse üksteist ja teisalt üritatakse oma seisukohti õigustada.

Selles näites esineb kolm pööratud polaarsusega küsimust (rida 16, read 29-30). Juba näitelõigu alguses (read 1-2) avaldab A Contra kohta oma arvamuse, mida võib lugeda selles vestluskatkes oleva vaidluse alguspunktiks. Siit alates on vestlejate seisukohad ja väited järjest teravamad (nt rida 3). Teiseks vaidluse seisukohalt oluliseks vooruks on A seisukoht ridadel 14-15, milles A jääb oma esimese seisukoha juurde (read 1-2) ja millega lisab veelgi teravust juba käimasolevale vaidlusele. Teravust lisab ka naer vooru lõpus. ei järgmise vooru algul (rida 16) väljendab vastuolu A ja B arvamuste vahel ja näitab, et B ei nõustu A-ga. ei-le järgneb B pööratud polaarsusega miks-küsimus miks ta ei või olla, millega B astub Contra kaitseks välja. Selle PPK-ga väljendab B seisukohta, et Contra võib olla küll kirjanik. Poole vooru pealt (rida 17) tuleb C välja omapoolse seisukohaga ja kasutab erimeelsuse väljendamiseks samuti $e i$-algulist vooru, nagu B-gi real 16 on teinud.

Real 20 algatab A paranduse, sest ta ei kuulnud köhimise tõttu $\mathrm{C}$ viimase vooru lõppu. $\mathrm{C}$ asemel aga algatab vooru hoopis $\mathrm{B}$, kes esitab väga isiklikuks minnes A-le süüdistuse sina pole ka midagi. Viimase sõna ajal viib $\mathrm{C}$ paranduse läbi. Ridadel 21-26 A ignoreerib B juttu ja reageerib C jutule.

Pööratud polaarsusega küsimused ridadel 29 ja 31 on reageering B seisukohale (rida 27, [ega `sina ei ole] ‘arvustaja siin, ‘mitte `mingi[sugune.]). Tegemist on väga isikliku ja halvustava seisukohaga, mis mõnevõrra kordab ja samas täiendab juba eespool öeldud samaväärset hinnangut (sina pole $k a$ midagi, rida 21). Seisukoht võib olla sellepärast esitatud nii teravalt, kuna paarile eelnevale B voorule A ei reageerinud ja nüüd kasutab B sellist „äärmuslikku" väljendust, et tähelepanu saada. PPK, mis asub real 29 , on selle seisukohaga otseselt seotud. Sellele viitavad lausungites esinevad sõnad arvustaja ja arvustada. PPK väljendab eelneva seisukohaga mittenõustumist, seega võib lugeda seda naabruspaari seisukoht-mittenõustumine järelliikmeks.

Nagu eespool mainitud, on tegemist vaidlussituatsiooniga. Enne analüüsitavaid küsimusi esineb palju pealerääkimist, mis on üheks märgiks sellest, et vaidlus on kulmineerumas. Küsimustega kas 'minul ei o(h)legi õigus `arvustada või ja kas me ei `ela demo`kraatlikus `vabariigis või esitab A B-le vastuseisukoha. PPK-dega edastab A küsimuse vastaspolaarsuselt väiteid, mis võiksid sõnastatud olla järgnevalt: Mul on ka õigus arvustada ja Me elame demokraatlikus vabariigis. Esimene küsimus on isiklikust seisukohast esitatud, teine küsimusena esitatud argument on tugeva üldteadmise põhine. PPK real 31 kindlustab ja toetab juba eelneva PPK-ga esitatud seisukohta. Küsimusele kas 'minul ei o(h)legi õigus ‘arvustada või võib A oodata ka vastust. Sellele viitab 0.8-sekundiline paus (rida 30). Reaktsioon järgnebki, aga alles pärast teist küsimust. B reageerib A voorule kõigepealt real 32 partikliga nooh?, mis on öeldud tõusva intonatsiooniga. Sellest võib järeldada, et B mõtleb, kuidas nii tugevatele argumentidele vaidluses vastata.

Kuigi vestluses osaleb rohkem inimesi, võib arvata, et küsimusena vormistatud väited on suunatud otseselt B-le, kes on eelnevas voorus A-d halvustanud. Siiski real 33 sekkub ka C, kes vastab A küsimusele otseselt väitega, mis sisaldus juba küsimuses endas. Pööratud polaarsusega küsimusele (rida 29) 
reageerib üks kaasvestlejatest seisukohaga nõustumisega (rida 33), teine vestleja mittenõustumisega (rida 35).

Kolmest vestluskaaslasest ei reageeri keegi A teisele küsimusele (kas me ei `ela demokraatlikus `vabariigis või). Põhjus võib olla selles, et küsimus puudutab tugevat üldteadmist, mida keegi ei taha vaidlustada, erinevalt esimesest küsimusest, mis puudutab vastajate jaoks tuttavat inimest (A-d) ja tema õigusi. Samuti tasub tähele panna seda, et teine küsimus on öeldud naerdes, mis juba iseenesest väljendab, et seda lausungit ei pea vestluskaaslased niiöelda tõsiselt võtma.

Järgmises näites (4) on taaskord tegemist vaidlussituatsiooniga. Omavahel räägivad S, M ja J. S on M-i onunaine ja J on hea perekonnatuttav. Vestluse teemaks on erinevad murrakud, üleüldine normikeel ja inimeste tegelik keelekasutus. Kuigi vestlejad on kõik ühel seisukohal, vaidlevad nad vastu ühiskonna üldistele normidele ja tavadele. Antud juhul on nad selle poolt, et inimesed võiksid rääkida nii, nagu nad tahaksid, mitte ei peaks pidevalt järgima kirjakeele norme.

(4)

$01 \mathrm{~J}: \quad$.hhh see on jah. aga neid jah (0.4) no=ku=akkad `meelde tuletama eks neid `sõnu

02 oli=jo=`palju.

$03 \mathrm{M}:\{\mathrm{mhmh}\}$

$04 \mathrm{~J}: \quad \mathrm{mt}$ mis olid `noh nisugused `eriskummalised.

$05(0.5)$

$06 \mathrm{J:}$.hh[hhhhhh] mõni oli `niisukene et noh et ega praegult `nooremad inimesed ei

$07 \mathrm{~S}: \quad *\left[\{\right.$ eks neid $]\{\text { jah }\}^{*}$

$08 \mathrm{~J}$ : ‘saagi aru `mis ta [tähendab.]

$09 \mathrm{M}: \quad$ [ei `saagi] aru [jah.]

$10 \mathrm{~S}: \quad$ ['noo]jah? $\{---\}$.

$11 \mathrm{~J}: \quad$ * jah igasugused väljendid. *

$12 \mathrm{~S}: \quad$ Silvit ma `vahetpidamata siin igatsugu sõnadega \$ $\$$ harin,\$ .hh Karla vahest ota

13 `mis `mis sõna peale ta alati `õiendab mu kallal et ei (0.6) @ ei `öelda

14 niimoodi=et, @ (1.4) et kudas sa `räägid et sa räägid ju `valest-, m: ma 'tahangi

$15 \$$ `r(h)ääkida `valesti, no `kellele see

16 ['kurat korda läheb`k][uidas ma räägin .hhh]\$

$17 \mathrm{~J}: \quad$ [no`jah ke-`kelle se `asi on]

$18 \mathrm{M}$ : [PEAASI ET `ARU SAADUD.]

$19 \mathrm{~J}:$ no[jah]

$20 \mathrm{~S}$ : [`küll] ma `siis `räägin korralikult, kui selleks `vajadust on=eksole, miks ma

21 pean `r(h)ääkima kogu aeg niugest `mingisugust`kirjakeelt= noh. .hhh

$22 \mathrm{~J}:$ jaa

$23 \mathrm{~S}: \quad$ kellele 'kurat seda `vaja läheb.

$24(0.7)$

$25 \mathrm{~J}: \quad$ ei ['kellelegi] .hh (0.8) ei 'KELLEGILE. 
$26 \mathrm{~S}: \quad[\{--\}]$

$27(0.6)$

$28 \mathrm{~S}:$ mjah

$29 \mathrm{M}$ : `jaa [hakkame] nüd `vaidlema [hehehehehehe ] ((lõbusalt))

$30 \mathrm{~J}: \quad$ [sin=oli] [jaa hehehehehe]

$31 \mathrm{~J}: \quad$ oli jah ei `kellegile.(0.4) sin oli jah [see veel `ka]

$32 \mathrm{~S}:(($ torisedes $))$

[\% ei `kellegi][le või 'kellelegi \%]

$33 \mathrm{M}$ :

34 'kirjutad,

[peaasi et sa `õigesti]

$35 \mathrm{~S}: \quad[$ noojah]

Näites on neli pööratud polaarsusega küsimust (read 15-16; 17; 20-21; 23). Sekventsiaalselt võib kõiki neid PPK-sid käsitleda kui järelliikmeid vestluses mitteosaleva Karla seisukohale (kudas sa ‘äägid et sa räägid ju `valest(rida 14)), sest sisuliselt vaidlustavad need kõik Karla arvamust, et tuleb rääkida normikeele kohaselt. PPK-d väljendavad Karla seisukohaga mittenõustumist ja esitavad sellele vastuväiteid. Samal ajal aga vaidlustavad PPK-d ka ühiskonna tavasid.

Selle näite esimene PPK no `kellele see `kurat korda läheb `kuidas ma räägin on kõige selgemalt naabruspaari seisukoht-mittenõustumine järelliige. Esiliige on juba eespool mainitud Karla seisukoht (rida 14).

Real 17 esitab J oma nõusolekuvooru, mis on samuti väljendatud sarnase pööratud polaarsusega küsimusega (no`jah ke- `kelle se ‘asi on), kinnitamaks S-i seisukohti. Ei saa väita, et nojah oleks nõusolek eelneva PPK-ga, sest J-i voor algab enne, kui S on jõudnud oma küsimuse lõpetada. nojah võib olla (hilinenud) reaktsioon seisukohale $m a$ `tahangi ' $r(h) \ddot{a ̈ a k i d a ~ ' v a l e s t i . ~ P a ̈ r a s t ~}$ nojah-i pööratud polaarsusega küsimuse konstruktsiooni kasutamine võib olla mõjutatud S-i pööratud polaarsusega küsimusest.

Pööratud polaarsusega küsimus ridadel 15-16 on liitlause. Pealause moodustab PPK esimene osa no `kellele see `kurat korda läheb`; teine osa kuidas ma räägin on kõrvallause ja täiendab esimest. M tõlgendabki esimest osa juba tervikliku üksusena ja näeb võimalust alustada oma vooru, mis tuleb pealerääkimisena ja on valjemalt öeldud (rida 18). Selle vooruga väljendab ka M ühtehoidmist S-i ja J-i seisukohtadega.

Ridadel 20-21 oleva PPK-ga ('miks ma pean `r(h)ääkima kogu aeg niugest 'mingisugust 'kirjakeelt=noh.), mis sisaldab tugevat hinnangut, vaidlustab S taaskord fakti, et on vaja rääkida korrektses kirjakeeles. Jällegi vaidlustab ta nii Karla arvamust kui ka üleüldist hoiakut ühiskonnas. J reageerib küsimusele partikliga jaa (rida 22), mis näitab, et ta nõustub S-i öeldud arvamusega, ja tõlgendab S-i küsimust kui seisukohta.

Real 23 on veel üks pööratud polaarsusega küsimus (`kellele `kurat seda vaja läheb), mis sisaldab tugevat hinnangut (ka ilma vandesõnata). J vastab küsimusele otsese vastusega, millega võiks vastata infoküsimusele (rida 25). Pärast pausi esitab J meelega grammatiliselt vale vormi, näidates, et ta võib rääkida, kuidas tahab. Sellega toob ta vestlusesse irooniat. Sellele vastusele ei reageeri kohe keegi, pärast pausi kinnitab seda S (rida 28). Real 29 kinnitab jaa-ga eelnevat ka M ja lisab oma vooruga veelgi irooniat. Kuigi see PPK on sisuliselt nii Karla seisukoha kui ka teiste vestlejate esitatud seisukohtade järelliige, moodustab see koos järgneva otsese vastusega ka naabruspaari küsimus-vastus, mille puhul vaadeldav PPK on hoopis esiliige. 
Reageerimine PPK-le selles avalduva seisukohaga nõustumise või mittenõustumisega on nende retooriliste küsimuste puhul kõige levinum reageerimisviis. See kinnitab tõsiasja, et vastuvõtjad tõlgendavad PPK-sid pigem seisukohtadena kui küsimustena. Asjaolu, et PPK võib olla ka reaktsioon talle eelnevale seisukohale, tõestab samuti seda, et PPK-de peamine funktsioon on seisukoha edastamine.

5.1.2. Küsimus-vastus naabruspaar. Küsimus-vastus naabruspaarist võib rääkida juhtudel, kui PPK-le vastatakse otseselt nagu infoküsimusele, hoolimata sellest, et pööratud polaarsusega küsimuste vastuse ootus ei ole nii tugev kui infoküsimuste puhul.

Analüüsitud vestlustes tuli esile vaid kolm näidet, milles kaasvestleja käsitleb PPK-d infoküsimusena. Siiski nende näidete puhul ei ole tegemist valesti mõistmisega, vaid võib arvata, et PPK-d on teadlikult käsitletud infoküsimusena. Ühte nendest vestlustest vaatlen lähemalt järgmisena.

Näites 5 vestlevad omavahel ema (V), ${ }^{5}$ tütar (R) ja tütre sõber (E). Jutt käib erinevatest teedest ja kohvidest. Terve vestlus käib naljatlevas ja iroonilises toonis.

$01 \mathrm{R}: \quad . \mathrm{hh}=`$ noo=se `must=võ (0.2) `kollane.

$02(1.0)$

$03 \mathrm{E}$ : kollast võib \{ka juua.\}

$04(0.3)$

$05 \mathrm{R}$ : mis `vahe sel 'mustal=ja kollasel=on

$06(0.5)$

$07 \mathrm{E}: @$ @maitse `vahe?@

$08(0.4)$

$09 \mathrm{R}: \quad$ ei=ole.

10 (.)

$11 \mathrm{E}$ : `on ['küll.]

$12 \mathrm{R:} \quad$ [mqm]

$13 \mathrm{E}$ : oopis `teine `maitse=on, `mis=sa `seletad.

14 (1.3)

$15 \mathrm{R}$ : 'vaevalt.

16 (1.0)

$17 \mathrm{E}$ : ei ‘tiia sina ka midagi,

$18(0.2)$

19 R: \$ no ikka `tean 'küll. \$

20 (1.5) ((mingi kõlks))

$21 \mathrm{E}: \quad>$ oled=sa=seda `musta `joond < ‘üldse=vä.

22 R: @m(h)mudugi `ole:n.@

Sekventsiaalselt on võimalik PPK-d selles näites tõlgendada järjendi naabruspaar küsimus-vastus esiliikmena. PPK-le (rida 5) järgneb otsene vastus (rida 7). Küsimusele järgnev paus (rida 6) näitab, et on olemas vastuse ootus või vähemalt soov, et teine kõneleja võtaks vooru.

Esmapilgul on käsitletavat küsimust keeruline tõlgendada PPK-na, sest see tundub kontekstist eraldi vaadelduna infoküsimus ja R-il võib olla tõesti

${ }^{5} \mathrm{~V}$ ei võta selles näitelõigus sõna, kuid on vestlussituatsioonis osaleja. 
soov teada saada, mis vahe on mustal ja kollasel teel. Samuti võib esialgu E vastuse sisu järgi oletada, et vastuvõtja on analüüsinud seda küsimust infoküsimusena ja ta annabki R-ile infot, et nendel teedel on maitse vahe. Kui aga vaadelda E kõnevooru üksikasjalikumalt, selgub, et tema vastus ei ole neutraalselt esitatud: reageerimisel PPK-le on kõneleja toon muutunud, ehk teisisõnu, vastaja on vooru esitanud oma tavapärasest kõnest erinevalt. Sellest võib järeldada, et pakutud vastus ei ole tõsiselt võetav ja vastaja on analüüsinud vaadeldavat küsimust PPK-na.

Seda, et vaadeldav küsimus on PPK, kinnitavad ka E voorud alates realt 9. Sellest ja järgmistest kõnevoorudest selgub, et küsimuse esitaja $R$ ei olegi $\mathrm{E}$ vastuses pakutavast infost huvitatud, vaid hakkab talle vastu vaidlema. Sõbralik vaidlus, mis algab pärast vastust PPK-le, jätkub näitelõigu lõpuni. Seega võib järeldada, et selles näites analüüsitud küsimus mis `vahe sel 'mustal=ja kollasel=on sisaldab vastupidist seisukohta mustal ja kollasel pole mingit vahet.

Selles näites tuli vastaja kõnetoonist välja, et PPK-le järgnenud otsest vastust ei saa nii-öelda tõsiselt võtta, kuid analüüsitud vestluste hulgast tuli esile ka näide, milles vastaja vastusvoorus on midagi, mis lisab vestlusesse irooniat ja pöörab sellega olukorra naljaks (näide 4, rida 25).

Otseste vastuste kohta võib kokkuvõtvalt öelda, et kuigi PPK vastuvõtja teab, et tegemist on retoorilise küsimusega ja vastus sellele on ilmselge, võib ta teadlikult vastata niimoodi, nagu vastatakse infoküsimustele, et lisada või rõhutada juba vestlusesse tekkinud irooniat ja huumorit.

Eespool toodud näited kajastavad seda, millised on pööratud polaarsusega küsimusest lähtuvad reaktsioonivoorud, kuid esineb ka selliseid olukordi, mil vastus/reaktsioon küsimusele jääb üldse saamata.

\subsection{Pööratud polaarsusega küsimused, mis ei kuulu naabruspaari}

Selle jaotuse juures olen samuti lähtunud vestluskaaslaste tegelikust reaktsioonist. Selle alajaotuse PPK-d ei kuulu naabruspaari, sest PPK-le ei järgne vooru (tegevust), mille põhjal oleks võimalik jagada sekventsi esi- ja järelliikmeks.

Pööratud polaarsusega küsimused, millele ei järgne reaktsiooni, asuvad üldjuhul pikemas kõnevoorus. Reaktsioonita võivad jääda PPK-d, mis esinevad näiteks suulises jutustuses. Järgmises näites (6) kasutatakse PPK-d jutustuse alustamiseks. Vestluses on neli osalejat: IT, ST ja AT on sugulased ja KM on nende sõber.

$01 \mathrm{KM}$ : `minu isa on ka see `kaitse `liitlane nendel on [`ka nüüd `šeif]id on

02 AT:

03 kõht `püs[ti.] ((koerale))

[kodus.]

[Älfi] [kesse`ma]gab

$04 \mathrm{KM}: \quad[\mathrm{e}] \mathrm{ma}$ naeris=et `ennem peetakse `noor `sõda maha kui `meie isa

05

06 IT:

07 ST:

ükskord oma `püssi k(h)ätte [s(h)aab.] [mhemhe] ((kostab nõudekolinat))

[noh]

[hehehehe] [hehe] 
08 IT: no `mis sest `kasu, see (.) `Toilast see `Alde Juss, (0.2) `limunaadis on

09 me`haanikus $(0.9) * \mathrm{ee}^{*}(0.3)$ no Juss ta `õige nimi=ei=ole=aga `Alde ta 'ongi

10 seal. (1.0) temal `kõik `vägev `seif ja i- i- ise me`haanika=mees, `tõesti no=et

$11($.

$12 \mathrm{KM}: \mathrm{mhmh}$

13 IT: seda ikka `annab lahti `muukida. (0.7) `süda`päeval keset`Toila tal on enne

14 `seda (0.2) post`kontorit Toilamõisa küla vahel.

$15(0.8)$

16 IT: ‘käidi `sies, (0.3) muugit[i viidi tal=see `pukk] püss

$17\{-\}: \quad[\{---\}]$

18 IT: $\min \left[\mathrm{ema}=\mathrm{ja}={ }^{\prime} \operatorname{mis}\right.$ tal viel, puhas] vuuk tehti ['vobsem.]

$19\{-\}: \quad[\{----\}]$

Analüüsitav PPK no mis sest kasu asub vooru alguses (rida 8) ja see moodustab jutustuse sissejuhatuse sekventsi (Routarinne 1997: 140). IT jutustuse esitamine on ajendatud vestluse teemast, milleks on seifid ja see, kui kindlad need on. Esimest korda vihjab IT sellele, et tal on midagi öelda, real 6. Ta ei oota võimalikku vooruvahetuskohta, vaid alustab KM-i pooleliolevale voorule pealerääkimist. Pealerääkimine võib olla tingitud sellest, et IT on saanud piisavalt infot ja ta ei pea vajalikuks kaasvestleja vooru lõpuni kuulata.

IT teab juhtumit, kus ühel inimesel varastati seif tühjaks, ja pööratud polaarsusega küsimusega teeb selle loo jutustamiseks sissejuhatuse (rida 8). Jutustusele eelneb tavapärane vestluse ülesehitus, milles kõnelejad vahetuvad kordamööda ja ükski vestlejatest ei räägi pikalt. Kuigi senise vestluse struktuuriga võrreldes alustab PPK vestluses midagi uut (jutustust), on küsimus tihedalt eelmise vooruga seotud. Küsimus algab partikliga no, mis sisaldab endas infot, et sellele järgneb eelneva vooruga seotud tekst ja samas no projitseerib teatud vastuolu eelnevale jutule. PPK kannab endas kogu järgneva jutu mõtet. Küsimusega väidab IT, et seifidest pole kasu. Küsimusele järgnev jutt toetab PPK-ga väljendatud seisukohta ja seletab täpsemalt, miks seifidest kasu pole.

Võib oletada, et PPK (rida 8) ei oota endale reaktsiooni, sest küsimus on esitatud poollangeva intonatsiooniga ja kohe sujuvalt järgneb sõna see, mis näitavad, et voor on jätkumas. Mikropaus pärast PPK-d ja see-d on väike takerdumine, mis on tavapärases kõnes üsna levinud. Vestluskaaslastest ei reageeri keegi PPK-le. M-i $m h m h$ real 12 on tavapärane tagasiside vahend, mis väljendab, et vestluskaaslane jälgib jutustust.

Pööratud polaarsusega küsimuse funktsioon on sekventsiaalselt jutustuse sissejuhatamine ja seose loomine eelmise vooruga. Sisuline funktsioon on vastanduse väljendamine. Pööratud polaarsusega küsimus ilmneb vestluskontekstis, kus inimestel on erinevad seisukohad käsiloleva teema kohta. KM edastab oma ema seisukoha, et seifid on kindlad, IT arvates ei ole. Siiski ei ole tegemist otseselt vaidlusega, vaid vestlejate vastuoluliste teadmistega.

PPK-d, millele ei järgnenud analüüsitud materjalis vastust, asuvadki kas kõnevooru algul, nagu näites 6, või kõnevooru keskel. Üldjuhul ei reageerita 
PPK-le siis, kui sellele ei järgne võimalikku vooruvahetuskohta, see tähendab, et intonatsiooniliselt on kõneleja küsimusvoor lõpetamata või pärast küsimust ei järgne pausi, mis oleksid kaks põhimärguannet vestluses, et teine kõneleja võtaks vooru üle. Samas leidus analüüsitud materjali hulgas ka näiteid, kus PPK-le järgneb paus, ja milles kõneleja ootab võib-olla kaasvestlejalt reaktsiooni, kuid mingil põhjusel kaasvestleja ei võta kõnevooru üle (näide 3 rida $30)$.

\subsection{Vahekokkuvõtteks}

PPK-de analüüs näitas, et olenevalt kaasvestleja reaktsioonist võivad need küsimused esineda vestluses erinevates järjendilistes ehk sekventsiaalsetes positsioonides.

Materjalist esile tulnud PPK-dele reageerimise võimalused on järgmised:

- $\quad$ seisukohaga nõustumine/mittenõustumine

- otsene vastus

- reaktsiooni puudumine

Sekventsiaalselt liigituvad analüüsitud PPK-d järgmiselt:

1. PPK-d, mis kuuluvad naabruspaari

- $\quad$ seisukoht-nõustumine/mittenõustumine naabruspaar

- küsimus-vastus naabruspaar

2. PPK-d, mis ei kuulu naabruspaari

Kuigi PPK-d võivad kuuluda vestluse erinevatesse osadesse, on nad seejuures nende osadega küllaltki kindlalt seotud. Pööratud polaarsusega küsimused on seotud nii küsimusele eelneva vooru või tegevuse kui ka sellele järgneva vooruga. Eelnev voor võib olla näiteks seisukohavõtt, mis kutsub esile PPK ja mis omakorda võib esile kutsuda kaasvestleja seisukoha. Võrreldes infoküsimustega, võib öelda, et PPK-d on suunatud vestluses pigem tahapoole, erinevalt infoküsimustest, mis on eelkõige orienteeritud küsimusele järgnevale voorule - vastusele (Koshik 2005: 36-37; 147-148). Kuigi ka infoküsimused võivad olla seotud neile eelneva vooruga, ei pruugi see alati nii olla. Näiteks infoküsimus võib alustada vestluses täiesti uut teemat, mis ei ole eelnevate voorudega kuidagi seotud. PPK-de puhul on asi vastupidi: PPK-dele järgnev voor ei ole nii oluline, sest vastus sisaldub juba küsimuses endas.

\section{Pööratud polaarsusega küsimuste suhtluslik eesmärk}

Pööratud polaarsusega küsimusi kasutatakse vestluses eelkõige selleks, et edastada väidet või seisukohta, millel on hinnanguline varjund. Need küsimused puudutavad enamasti küsijale ja vastuvõtjale tuttavaid seisukohti või sündmusi. Pööratud polaarsusega küsimused tulenevad üldjuhul vestluskaaslase eelnevalt produtseeritud voorust, milleks on mõni seisukoht või tegevus, mille pööratud polaarsusega küsimused tihtipeale vaidlustavad. Samuti võib pööratud polaarsusega küsimusega vaidlustada vestluskaaslase ideid või tõekspidamisi, mis on vestlejatele juba taustateadmisena teada (vt näide 3 ).

Kuigi sisuliselt ühendab kõiki analüüsitavaid küsimusi see, et nad väljendavad seisukohta, tuli materjalist esile ka selliseid küsimusi, mis puudutavad otseselt kellegi füüsilist tegevust. Sellised PPK-d näitavad, et küsimuse 
propositsiooniga esitatud tegevuse sooritamine on kõneleja meelest võimatu, mõttetu või soovimatu (kus ta läheb kui ta rääkida ei saa, vt näide 1).

Nende küsimustega esitatakse vestluskaaslasele nii öelda väljakutse. Väljakutset vastu võttes peab vastaja kinnitama või põhjendama oma seisukohta. Näidetes esitati väljakutse ka vestluses mitteosalevatele inimestele, hoolimata sellest, et sel hetkel ei saa need inimesed oma seisukohtade eest seista (näide 4).

Põhjuseks, miks valivad kõnelejad seisukoha edastamiseks küsimuse vormi, võib olla see, et pööratud polaarsusega küsimused teevad samaaegselt mitut asja (avaldavad kõneleja seisukohta, annavad hinnangu millelegi, kutsuvad üles kaasvestlejat ennast õigustama) (vrd kas me ei ela demokraatlikus vabariigis või ja me elame demokraatlikus vabariigis), mõjudes seetõttu ka tugevamate väidetena kui otsese väitlausega edastatud väide. Küsimuse vormis väitele on seega vestluskaaslastel raskem vastuväidet esitada. Vaidlusolukorras pööratud polaarsusega küsimuse esitaja tahab, et temaga vaidleja ütleks ise välja, mis on küsija arvates õige seisukoht. Samas teatud vestlustes võib küsimuse vorm olla hoopis vaidlusolukorra pehmendaja, mis tähendab, et midagi öeldakse kaudselt, mitte otse. Näiteks ironiseerivad PPK-d ei pruugi mõjuda nii jäikade seisukohtadena.

\section{Kokkuvõte}

Artiklis analüüsisin ühte retoorilise küsimuse liiki - pööratud polaarsusega küsimust - eesti igapäevase argisuhtluse taustal. Otsisin vastust küsimustele, kuidas tegelikus suhtluses käsitletakse selliseid küsimusi ja mis suhtluseesmärke need küsimused seejuures täidavad. Selle väljaselgitamiseks analüüsisin 42 pööratud polaarsusega küsimuse ülesehitust, järjendilist asukohta ja vestluskaaslaste reageerimist nendele.

Analüüs näitas, et pööratud polaarsusega küsimusi moodustatakse samamoodi kui infoküsimusi. See tähendab, et kontekstist eraldi vaadelduna võib osutuda raskeks kindlaks määrata, kas tegemist on pööratud polaarsusega küsimuse või infoküsimusega. Pööratud polaarsusega küsimused on seega vestluskontekstiga tihedalt seotud. Need pööratud polaarsusega küsimused, mis ei ole vestluskontekstiga niivõrd seotud, on osaliselt või täielikult kinnistunud.

Vestluses jääb küsimuse vastuvõtja otsustada, kuidas kuuldud küsimust tõlgendada ja kuidas sellele reageerida. Tüüpiliselt reageeritakse pööratud polaarsusega küsimusele seisukohavõtuga, kuna see on iseenesest samuti seisukoht. Samuti võib pööratud polaarsusega küsimus, mis on sisuliselt retooriline küsimus, saada vastuseks otsese vastuse. Otsene vastus pööratud polaarsusega küsimusele ei pruugi tähendada, et vastuvõtja on küsimust valesti tõlgendanud. Kuigi vastuvõtja teab, et vastus retoorilisele küsimusele on endastmõistetav, võib ta reageerida teadlikult otsese vastusega, et tuua vestlusesse huumorit. Pööratud polaarsusega küsimused, mis asuvad ühe kõneleja pikema kõnevooru algul või keskel, võivad jääda ka kaasvestleja reaktsioonita. Olenevalt sellest, kas pööratud polaarsusega küsimusele reageeritakse vestluses või mitte, jagunevad nad küsimusteks, mis kuuluvad naabruspaari (nt küsimus-vastus naabruspaar), ja küsimusteks, mis ei kuulu naabruspaari. Suhtluse seisukohalt on reaktsioonid pööratud polaarsusega 
küsimustele orienteeritud tegevusele, mis selle küsimusega läbi viidi. See sõltub vestluskontekstist. Seetõttu saab vaidluses näiteks süüdistav pööratud polaarsusega küsimus reaktsiooniks enda õigustamise. Kui aga vestluses on mänguline või irooniline toon, siis pööratud polaarsusega küsimusele vastatakse samuti irooniaga.

Pööratud polaarsusega küsimuste suhtluses kasutamiseks on kõnelejatel erinevad eesmärgid. Eelkõige kasutatakse neid, et teha teatavaks oma seisukoht, mis on tihtipeale hinnanguline. Vaidlustes õigustab kõneleja pööratud polaarsusega küsimuste abil oma arvamust ja samal ajal ironiseerib või süüdistab kaasvestlejat. Kaasvestlejad võtavad pööratud polaarsusega küsimust kui väljakutset, et oma arvamust õigustada. Ühelt poolt teravdab pööratud polaarsusega küsimuste kasutamine vastuolu kõnelejate seisukohtade vahel, teisalt võib see muuta vestluse hoopis huumorikamaks.

Artikli valmimist on toetanud Eesti Teadusfond (grant 8558).

\section{Kirjandus}

Couper-Kuhlen, Elizabeth, Selting, Margret 2001. Introducing Interactional Linguistics. - Studies in Interactional Linguistics. Toim Margret Selting, Elizabeth Couper-Kuhlen. Amsterdam-Philadelphia: John Benjamins Publishing Company, lk 1-22.

D r e w, Paul, He rit a g e, John 2006. Introduction. - Conversation Analysis. Kd 1. Turn-taking and repair. Toim Paul Drew, John Heritage. London-Thousand Oaks-New Delhi: Sage Publications, lk xxi-xxxvi.

EKG II = Mati Erelt, Reet Kasik, Helle Metslang, Henno Rajandi, Kristiina Ross, Henn Saari, Kaja Tael, Silvi Vare, Eesti keele grammatika II. Süntaks. Lisa: kiri. Tallinn: Eesti Teaduste Akadeemia Keele ja Kirjanduse Instituut, 1993.

I 1 i e, Cornelia 1995. What Else Can I Tell You? A Pragmatic Study of English Rhetorical Questions as Discursive and Argumenative Acts. Stockholm: Almqvist \& Wiksell International.

Ka s t e r p a l u, Riina, G e r a s s i m e n k o, Olga 2006. Vestlusanalüüs. - Teoreetiline keeleteadus Eestis II. Toim Ilona Tragel, Haldur Õim. (Tartu Ülikooli üldkeeleteaduse õppetooli toimetised 7.) Tartu: Tartu Ülikooli Kirjastus, lk 112126.

K e e v a 1 li k, Leelo 2002. Grammatika suhtluses. - Teoreetiline keeleteadus Eestis. Toim Renate Pajusalu, Ilona Tragel, Tiit Hennoste, Haldur Õim. (Tartu Ülikooli üldkeeleteaduse õppetooli toimetised 4.) Tartu: Tartu Ülikooli Kirjastus, lk 89-104

Koshik, Irene 2005. Beyond Rhetorical Questions. Assertive Questions in Everyday Interaction. Amsterdam-Philadelphia: John Benjamins Publishing Company.

Li d d i c o at, Anthony J. 2007. An Introduction to Conversation Analysis. London-New York: Continuum.

M e t s l a ng, Helle 1981. Küsilause eesti keeles. Eesti NSV Teaduste Akadeemia Keele ja Kirjanduse Instituut. Tallinn: Valgus.

Pajusalu, Renate 2006. Multiple motivations for meaning of an elative wh-construction in Estonian. - Trames: Journal of the Humanities and Social Sciences, nr 10 (4), lk 324-340. 
Q u ir k, Randolph, Gre e n b a u m, Sidney, Le e c h, Geoffrey, Sva r tvik, Jan 1976. A Grammar of Contemporary English. Longman.

R o u t a r i n n e, Sara 1997. Kertomuksen rakentaminen. - Keskustelunanalyysin perusteet. Toim Liisa Tainio. Tampere: Vastapaino, lk 138-155.

S a cks, Harvey, S ch e gl off, Emanuel, Jeffer s o n, Gail 1974. A Simplest Systematics for the Organization of Turn-taking for Conversation. - Language, nr 50 (4), lk 696-735.

S chegl off, Emanuel, J effers o n, Gail, S a cks, Harvey 1977. The Preference for Self-correction in the Organization of Repair in Conversation. - Language: Journal of the Linguistic Society of America, nr 52 (2), lk 361-382.

S c h e g l o ff, Emanuel, S a c k s, Harvey 1973. Opening up Closings. - Semiotica: Journal of the International Association for Semiotic Studies, nr 4, lk 289-327.

\section{Transkriptsioonimärgid}

1. Li i gendusüksused

Lausungit lõpetav (langev) intonatsioon märgitakse punktiga.

Lausungi sees olevad intonatsiooniliste üksuste piirid (poollangev intonatsioon) märgitakse komaga.

Tõusva intonatsiooniga lõppeva üksuse lõpus on küsimärk.

2. P a u sid

(.) - mikropaus: 0.2 sekundit või lühem

(1.2) - pausi pikkus sekundites

3. Kõne prosoodilised ja paralingvistilised omadused

- rõhk

$>\ldots \ldots .<$ (sissepoole osutavad nooled) kiirendatud lõik

$<\ldots . .>$ (väljapoole osutavad nooled) aeglustatud lõik

t:ere - häälikuvenitused märgitakse kooloniga

@....@ - hääle kvaliteedi muutumine (kõne jäljendamine, kirjutatud teksti lugemine jms)

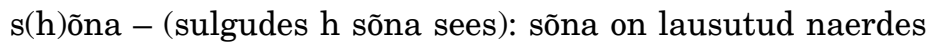

$\$ \ldots . . . \$$ - naerva häälega öeldud sõna või pikem lõik

* ..... * - vaiksem jutt

si- - sõna poolelijätmine

tulin=ja - kokkuhääldatud sõnad

4. Pealerääkimised ja haakumised

[ - pealerääkimise algus

] - pealerääkimise lõpp

$=-$ kaks iseseisvat üksust on hääldatud kokku

5. Ebaselgused ja kommentaarid

\{või\} - halvasti kuuldud tekstilõik või kõneleja nimi

$\{--\}$ - ebaselgeks jäänud sõna või kõneleja

\{---\} - pikem ebaselgeks jäänud lõik

((tuleb laua juurde)) - litereerija kommentaarid ja seletused situatsiooni kohta 


\section{Reversed Polarity Rhetorical Questions in Estonian Everyday Interaction}

Keywords: reversed polarity rhetorical questions, interactional linguistics, conversation analysis, Estonian everyday interaction

The article gives an overiew of reversed polarity rhetorical questions (RPQ-s) in Estonian everyday interaction. RPQ-s are rhetorical questions that convey strong reversed polarity assertions. The data for this article comes from the Corpus of Spoken Estonian of the University of Tartu. A total of $42 \mathrm{RPQ}$-s from different everyday conversations were analysed using the methodology of interactional linguistics and conversation analysis.

The article focuses on the grammatical construction, sequential position and interactional purposes of the RPQ-s. The analysis shows that the grammatical construction of RPQ-s does not differ from that of information asking questions. Therefore some RPQ-s can be interpreted as rhetorical only in a wider conversational context.

In the data analysed there occurred three different possibilities of responding to RPQ-s: (1) the recipients respond with a (dis)approval of the statement expressed in the question; (2) the recipients respond with a straight answer, and in some cases (3) RPQ-s get no response. Whether RPQ-s receive an answer or not, they can be sequentially divided into questions that are part of an adjacency pair (question - answer; statement - (dis)approval) and questions that are not.

The main function of these questions is to convey an assertion or a statement that can have an evaluative connotation. Most RPQ-s occur in positions where there is a contradiction in the interactants' opinions. RPQ-s may be argumentative, justifying, defensive, sarcastic or accusatory. The recipient of the question can be challenged by the question. Accepting the challenge the recipient takes a defensive position for her/his opinion.

Kirsi Laanesoo, PhD student, University of Tartu, kirsi.laanesoo@ut.ee 